\title{
Expanding the Genotypic Spectrum of Congenital Sensory and Autonomic Neuropathies Using Whole-Exome Sequencing
}

\author{
Jose-Alberto Palma, MD, PhD, Rachita Yadav, PhD, Dadi Gao, PhD, Lucy Norcliffe-Kaufmann, PhD,
} Susan Slaugenhaupt, PhD, and Horacio Kaufmann, MD, FAAN

Neurol Genet 2021;7:e568. doi:10.1212/NXG.0000000000000568

\section{Abstract}

\section{Objective}

To test the hypothesis that many patients presenting with congenital insensitivity to pain have lesser known or unidentified mutations not captured by conventional genetic panels, we performed whole-exome sequencing in a cohort of well-characterized patients with a clinical diagnosis of congenital hereditary sensory and autonomic neuropathy with unrevealing conventional genetic testing.

\section{Methods}

We performed whole-exome sequencing (WES) in 13 patients with congenital impaired or absent sensation to pain and temperature with no identified molecular diagnosis from a conventional genetic panel. Patients underwent a comprehensive phenotypic assessment including autonomic function testing, and neurologic and ophthalmologic examinations.

\section{Results}

We identified known or likely pathogenic genetic causes of congenital insensitivity to pain in all 13 patients, spanning 9 genes, the vast majority of which were inherited in an autosomal recessive manner. These included known pathogenic variants ( 3 patients harboring mutations in TECPR2 and SCN11A), suspected pathogenic variants in genes described to cause congenital sensory and autonomic syndromes (7 patients harboring variants in NGF, LIFR, SCN9A, and PRDM12), and likely pathogenic variants in novel genes (4 patients harboring variants in SMPDL3A, PLEKHN1, and SCN10A).

\section{Conclusions}

Our results expand the genetic landscape of congenital sensory and autonomic neuropathies. Further validation of some identified variants should confirm their pathogenicity. WES should be clinically considered to expedite diagnosis, reduce laboratory investigations, and guide enrollment in future gene therapy trials.

\author{
Correspondence \\ Dr. Palma \\ josealberto.palmacarazo@ \\ nyumc.org
}

MORE ONLINE

- Video

From the New York University School of Medicine (J.-A.P., L.N.-K., H.K.), New York, NY; and Massachusetts General Hospital Research Institute (R.Y., D.G., S.S), Boston.

Funding information and disclosures are provided at the end of the article. Full disclosure form information provided by the authors is available with the full text of this article at Neurology.org/NG.

The Article Processing Charge was funded by the authors.

This is an open access article distributed under the terms of the Creative Commons Attribution-NonCommercial-NoDerivatives License 4.0 (CC BY-NC-ND), which permits downloading and sharing the work provided it is properly cited. The work cannot be changed in any way or used commercially without permission from the journal. 


\section{Glossary}

CADD $=$ Combined Annotation-Dependent Depletion; FATHMM $=$ Functional Algorithm through Hidden Markov Models; gnomAD = Genome Aggregation Database; HSAN = hereditary sensory and autonomic neuropathy; LOFTEE = Loss of Function Transcript Effect Estimator; NGF = nerve growth factor; SIFT = Sorting Intolerant From Tolerant; SVM = support vector machine.

Congenital sensory and autonomic neuropathies are clinically and genetically heterogeneous disorders. ${ }^{1}$ Patients have reduced or absent sensation to pain and temperature frequently causing self-mutilations and ulcers, which can result in soft tissue infections or osteomyelitis. ${ }^{1}$ In addition, patients have a variable degree of autonomic dysfunction that may include anhidrosis, reduced production of tears, blood pressure fluctuations, or gastrointestinal disturbances.

Historically, syndromes with congenital insensitivity to pain have been classified as part of the hereditary sensory and autonomic neuropathies (HSANs). The current classification of HSAN is numerical, based on age at onset, inheritance pattern, and clinical features. ${ }^{2}$ Up to 8 types of HSANs have been now described. Each HSAN is caused by one or several mutations that affect specific aspects of sensory and autonomic neuronal development, resulting in variable phenotypes. Genetic causes of HSANs include pathogenic variants in SPTLC1, SPTLC2, RAB7, ATL1, DNMT1, ATL3 (HSAN1, usually adult onset), WNK1, KIF1A, FAM134B, SCN9A (HSAN2), ${ }^{3,4}$ IKBKAP (HSAN3), ${ }^{5}$ NTRK1 (HSAN4), ${ }^{6}$ NGF (HSAN5), ${ }^{7,8}$ dystonin (HSAN6), ${ }^{9,10}$ SCN11A (HSAN7), ${ }^{11}$ and PRDM12 (HSAN8). ${ }^{12}$ However, described pathogenic variants in the above-mentioned genes are not found in many patients presenting with congenital sensory and autonomic neuropathies, suggesting that additional genes are likely associated with HSAN. ${ }^{7}$ The HSANs can be transmitted as either autosomal dominant or recessive traits. Patients with autosomal dominant HSAN (HSAN1) usually present in adulthood, whereas autosomal recessive HSANs (HSAN2 to HSAN8) typically express at birth. ${ }^{13}$

Whole-exome sequencing, the analysis of the protein-coding exons of genes, has the potential to accelerate the diagnosis of patients with rare inherited neuropathies. ${ }^{14,15}$ We hypothesized that many patients presenting with a congenital sensory and autonomic phenotype have lesser known or unidentified mutations. To test this hypothesis, we performed wholeexome sequencing in a cohort of well-characterized patients with a clinical diagnosis of congenital sensory and autonomic neuropathy that had undergone unrevealing conventional genetic testing. Discovering genetic variants involved in the etiology of patients with congenital insensitivity to pain could expand the genotype-phenotype correlations and contribute to the development of personalized gene therapies.

\section{Methods}

\section{Study Design}

Consecutive patients with a phenotype consistent with congenital impaired sensation to pain and temperature with variable degree of autonomic dysfunction referred to the New York University Dysautonomia Center between July 1, 2013, and July 1,2019 , were eligible. Inclusion criteria were (1) congenital impaired or absent sensation to pain and temperature; (2) negative screening for mutations in genes causing early-onset HSAN including WNK1, FAM134B, KIF1A, IKBKAP (familial dysautonomia), and NTRK1 (congenital insensitivity to pain with anhidrosis) performed with a conventional genetic panel ordered by local pediatrician or geneticist; and (3) preserved muscle strength with no signs of motor neuropathy. All patients underwent a comprehensive medical and family history, physical and neurologic examinations, and cardiovascular autonomic (including venous plasma catecholamine levels in the supine resting position) and ophthalmologic evaluations. Neuroimaging, nerve conduction studies, polysomnography, and sural nerve biopsy were performed in some patients. We also reviewed the patients' history obtained from medical records including birth history, developmental history, and clinical/genetic metabolic evaluations.

\section{Genetic Analysis}

We reviewed all clinical genetic testing performed for each case. When a genetic diagnosis was not available, we performed research-based whole-exome sequencing. DNA extracted from blood obtained from the index case and both parents (trio analysis) underwent whole-exome sequencing using either the Agilent Technologies (Santa Clara, CA) SureSelect XTHuman All Exon v4 or Illumina (San Diego, CA) Rapid Capture Exome kit. Sequencing of 100 bp pairedend reads was obtained using Illumina HiSeq. Coverage was $>90 \%$ or $>80 \%$ meeting $20 \times$ coverage with the 2 methods, respectively. Read alignment, variant calling, and annotation were performed on a pipeline based on Burrows-Wheeler Aligner.

We called variants using human genome 19 coordinates. For undescribed variants, we used inheritance patterns and in silico predictions (PolyPhen ${ }^{16}$; Sorting Intolerant From Tolerant [SIFT], ${ }^{17}$ Combined Annotation-Dependent Depletion [CADD], ${ }^{18}$ Loss of Function Transcript Effect Estimator [LOFTEE], ${ }^{19}$ MutationTaster, ${ }^{20}$ Meta-support vector machine (Meta-SVM), ${ }^{21}$ and the Functional Algorithm through Hidden Markov Models [FATHMM ${ }^{22}$ ) to assess potential pathogenicity. The occurrence frequencies were obtained from control databases (including the Genome Aggregation Database $[\mathrm{gnomAD}]{ }^{23} 1000$ Genomes database, ${ }^{24}$ and dbSNP). We excluded variants with allele frequency $>0.5 \%$ in control populations. For homozygous mutations, we excluded homozygous variants in the latest version of gnomAD (v2.1.1). 

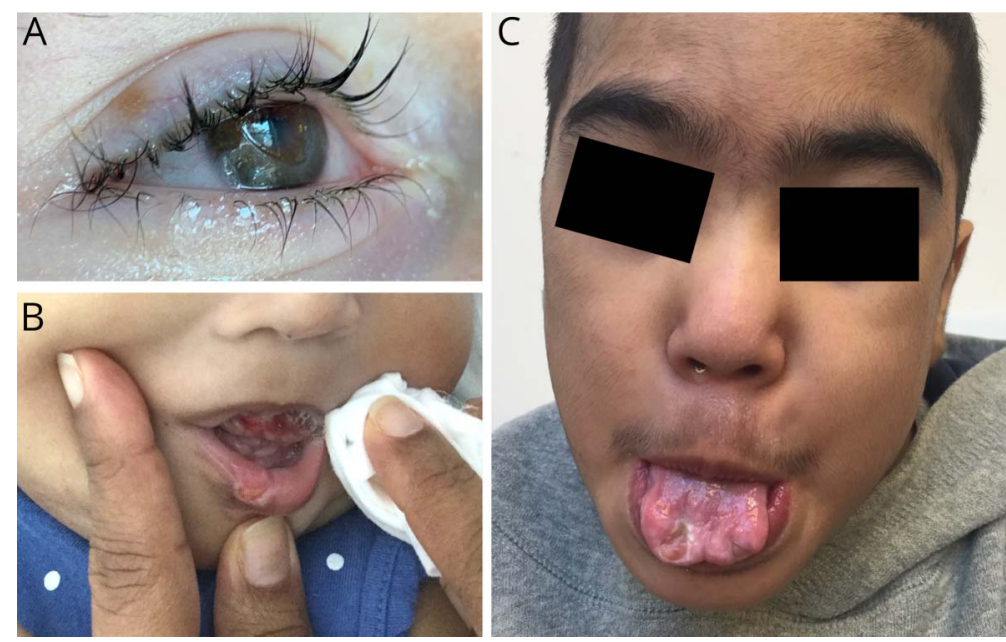

(A) Severe corneal ulceration in 15-year-old patient with a variant in the newly described gene PLEKHN1 (patient 9). (B) Lip and tongue automutilation in a 1-year-old patient with a novel likely pathogenic variant in PRDM12 (patient 13, this patient had an absent corneal reflex as documented in the online video 1). (C) Severe tongue automutilation in a 12-yearold patient with a novel likely pathogenic variant in LIFR (patient 6 , note also the facial hirsutism, a described feature of patients with Stüve-Wiedemann syndrome caused by LIFR mutations).

\section{Protein Structure Prediction}

To further explore the functional outcomes of some of the identified mutations predicted to be pathogenic, we investigated the effect of mutations in genes encoding sodium channels on the protein secondary structures. Wild-type protein sequences, mutated positions, original amino acid letters, and substitute amino acid letters were entered into MUpro (mupro.proteomics.ics.uci.edu) ${ }^{25}$ Change of free energy $(\Delta \Delta G)$ for each mutation was predicted using the SVM-based method. A negative $\Delta \Delta \mathrm{G}$ value denotes decreased stability, whereas a positive value indicates increased stability. For each mutation in genes encoding sodium channels, a sequence of 200 amino acids (from -100 to +99 flanking the mutated amino acid) was extracted and entered into PSIPRED (bioinf.cs.ucl.ac.uk/psipred). Default parameters were used to predict its secondary structure.

\section{Standard Protocol Approvals, Registrations, and Patient Consents}

We followed the STrengthening the REporting of Genetic Association Studies (STREGA) statement. ${ }^{26}$ The New York University School of Medicine Institutional Review Board approved this study. Written informed consent was obtained from all patients or guardians participating in the study.

\section{Data Availability}

Anonymized data will be shared by written request from any qualified investigator.

\section{Results}

\section{Cohort Phenotype}

We studied 13 patients from 10 families with a referral diagnosis of congenital sensory and autonomic neuropathy without signs of motor neuropathy. We confirmed reduced or absent sensation to pain and temperature in all patients, with mostly preserved sensation to fine touch. The first clinical signs of the disease became manifest between birth and age 6 months, the most common being tongue and lip mutilations in 8 patients (figure 1) and vomiting with aspiration suggesting neurogenic dysphagia in 5 patients. The degree and severity of autonomic involvement was variable and included reduced or absent basal production of tears in 11 patients, gastrointestinal disturbances (dysphagia in 9, gastroesophageal reflux in 4, nausea and vomiting in 4, and reduced gastrointestinal motility and constipation in 7), and either reduced (in 2) or excessive sweating (in 3). Cardiovascular autonomic function and plasma catecholamine levels were normal in all cases, except in patients with LIFR mutations who had paroxysmal episodes of hypertension and severe diaphoresis associated with high plasma norepinephrine levels and hyponatremia. The majority of the patients $(8 / 13)$ had corneal ulcers or other signs of corneal keratopathy with reduced production of basal tears and absent corneal reflex (video 1 , shows lack of corneal reflex in patient 13 who had a likely pathogenic variant in PRDM12). Delayed developmental milestones were seen in 8 patients, despite no signs of myopathy, motor neuron disease, or peripheral motor neuropathy. Sleep disorders were infrequent except in patients with TECPR2 and $S C N 9 A$ variants, who had central sleep apnea, and in patients who had LIFR and PRDM12 variants who had predominantly obstructive sleep apnea. The clinical characteristics of these patients are detailed in table 1 . All patients were alive at the time of writing.

\section{Identification of Genetic Variants}

We identified known or suspected genetic causes of congenital sensory and autonomic neuropathy in all 13 patients including known pathogenic variants (3 patients), suspected pathogenic variants in genes described to cause congenital sensory and autonomic syndromes (7 patients), and likely pathogenic variants in novel, unexpected genes (3 patients). The genetic characteristics of the described variants are listed in table 2.

\section{Described Genetic Pathogenic Variants}

\section{TECPR2}

Two unrelated patients of Ashkenazi Jewish ancestry had a homozygous known pathogenic variant (p.Leu440Argfs) in 
Table 1 Summary and Clinical Characteristics of Patients With Congenital Sensory and Autonomic Neuropathy, by Genetic Subgroup

\begin{tabular}{|c|c|c|c|c|}
\hline Characteristic & $\begin{array}{l}\text { SMPDL3A hom variants; } \\
\mathrm{n}=2 \text { (twin sisters) }\end{array}$ & $\begin{array}{l}\text { NGF hom variants; } \\
\mathrm{n}=2 \text { (siblings) }\end{array}$ & $\begin{array}{l}\text { LIFR hom variants; } \\
\mathrm{n}=\mathbf{2} \text { (siblings) }\end{array}$ & $\begin{array}{l}\text { TECPR2 hom variants; } \\
\mathrm{n}=2\end{array}$ \\
\hline Sex & $F, F$ & $F, F$ & $\mathrm{M}, \mathrm{M}$ & $\mathrm{F}, \mathrm{M}$ \\
\hline Origin & Irish & Indian & Pakistani & Ashkenazi \\
\hline Age at genetic testing & Both $14 \mathrm{y}$ & $8 y, 14 y$ & $8 y, 12 y$ & $3 y, 4 y$ \\
\hline $\begin{array}{l}\text { Age at first sign or } \\
\text { symptom identified }\end{array}$ & $\begin{array}{l}\text { Both } 6 \text { mo (corneal } \\
\text { insensitivity) }\end{array}$ & $\begin{array}{l}\text { Both } 6 \text { mo (tongue and } \\
\text { lip mutilations) }\end{array}$ & $\begin{array}{l}\text { At birth (GERD and respiratory } \\
\text { complications) }\end{array}$ & $\begin{array}{l}\text { At birth (vomiting and } \\
\text { aspiration) }\end{array}$ \\
\hline $\begin{array}{l}\text { Sensation to pain and } \\
\text { temperature }\end{array}$ & Severely reduced & Absent & Reduced & Reduced \\
\hline Sensation to fine touch & Reduced & Preserved & Preserved & Preserved \\
\hline Deep tendon reflexes & Absent & Present & Present & Reduced \\
\hline $\begin{array}{l}\text { Sensory nerve } \\
\text { conduction velocities }\end{array}$ & $\begin{array}{l}\text { Absent sensory nerve action } \\
\text { potentials }\end{array}$ & Normal & $\mathrm{N} / \mathrm{A}$ & N/A \\
\hline Sural nerve biopsy & $\begin{array}{l}\text { Loss of large and small } \\
\text { myelinated and } \\
\text { nonmyelinated neurons }\end{array}$ & N/A & N/A & N/A \\
\hline Basal tears & Absent & Absent & Reduced & Reduced \\
\hline Emotional tears & Present & Present & Present & Present \\
\hline Corneal abrasions & Present & Absent & Present & Present (punctate keratitis) \\
\hline $\begin{array}{l}\text { Self-mutilation in the } \\
\text { tongue, lips, or fingers }\end{array}$ & Yes $2(100 \%)$ & Yes $2(100 \%)$ & Yes $2(100 \%)$ & No \\
\hline Sweating & Normal & Absent & $\begin{array}{l}\text { Paroxysmal hyperhidrosis with } \\
\text { hyponatremia }\end{array}$ & Normal \\
\hline $\begin{array}{l}\text { Cardiovascular } \\
\text { abnormalities }\end{array}$ & No & No & Paroxysmal hypertension & Normal \\
\hline $\begin{array}{l}\text { Plasma } \\
\text { catecholamines levels }\end{array}$ & Normal & N/A & $\begin{array}{l}\text { Elevated norepinephrine during } \\
\text { paroxysmal hypertension }\end{array}$ & Normal \\
\hline $\begin{array}{l}\text { Gastrointestinal } \\
\text { abnormalities }\end{array}$ & $\begin{array}{l}\text { Neurogenic dysphagia and } \\
\text { sialorrhea } 1(50 \%)\end{array}$ & $\begin{array}{l}\text { Reduced motility } 2 \\
(100 \%) . \text { Necrotizing } \\
\text { enterocolitis } 1(50 \%) \\
\text { requiring colostomy }\end{array}$ & $\begin{array}{l}\text { Neurogenic dysphagia, sialorrhea, } \\
\text { gastroparesis, and nausea } \\
\text { accompanied by hyperhidrosis } \\
\text { and hypertension }\end{array}$ & $\begin{array}{l}\text { Neurogenic dysphagia, and } \\
\text { constipation }\end{array}$ \\
\hline $\begin{array}{l}\text { Sleep disordered } \\
\text { breathing }\end{array}$ & No & No & Obstructive sleep apnea & $\begin{array}{l}\text { Central sleep apnea, snoring, } \\
\text { and stridor }\end{array}$ \\
\hline $\begin{array}{l}\text { Orthopedic } \\
\text { abnormalities }\end{array}$ & $\begin{array}{l}\text { Frequent fractures and } \\
\text { neuropathic joints (ankles) } 2 \\
\text { (100) }\end{array}$ & Frequent fractures & $\begin{array}{l}\text { Bowing of legs, camptodactylia, } \\
\text { and frequent fractures }\end{array}$ & No \\
\hline Hyperlordotic spine & No & No & & \\
\hline $\begin{array}{l}\text { Sensorineural hearing } \\
\text { loss }\end{array}$ & $1(50 \%)$ & No & No & $1(50 \%)$ \\
\hline Muscle tone & Normal & Normal & Normal & Reduced \\
\hline Motor development & Normal & Normal & $\begin{array}{l}\text { Delayed, did not walk until } 2 \text { years } \\
\text { old }\end{array}$ & $\begin{array}{l}\text { Delayed, did not walk until } \\
2.4 \text { years old }\end{array}$ \\
\hline \multirow[t]{4}{*}{ Other features } & Reduced olfaction in 1 (50\%) & $\begin{array}{l}\text { Vesicoureteral reflux } 2 \\
(100 \%)\end{array}$ & Hirsutism & Neurodevelopmental delay \\
\hline & UPSIT: $34 / 40$ & & $\begin{array}{l}\text { Lung disease (bronchiectasis, } \\
\text { asthma, and restrictive lung } \\
\text { disease) }\end{array}$ & Proprioceptive ataxia \\
\hline & Mild dysarthria & & & Strabismus \\
\hline & Normal brain MRI & & & Thin corpus callosum 1 (50\%) \\
\hline
\end{tabular}

Abbreviations: GERD = gastroesophageal reflux disease; het = heterozygous; hom = homozygous. 
Table 1 (continued)

\begin{tabular}{|c|c|c|c|c|}
\hline $\begin{array}{l}\text { PLEKHN1 hom variant; } \\
\mathrm{n}=1\end{array}$ & $\begin{array}{l}\text { SCN9A hom variant; } \\
\mathrm{n}=1\end{array}$ & $\begin{array}{l}\text { SCN10A het variant; } \\
\mathrm{n}=1\end{array}$ & $\begin{array}{l}\text { SCN11A het variant; } \\
\mathrm{n}=1\end{array}$ & $\begin{array}{l}\text { PRDM12 het variant; } \\
n=1\end{array}$ \\
\hline$F$ & $\mathrm{M}$ & $M$ & $\mathrm{M}$ & $\mathrm{F}$ \\
\hline German & German/Irish & Caribbean & German/Italian & Caribbean \\
\hline $15 y$ & $9 y$ & $7 y$ & $16 \mathrm{mo}$ & $1 \mathrm{y}$ \\
\hline $\begin{array}{l}\text { At birth (hypotonia, GERD, and } \\
\text { vomiting) }\end{array}$ & $\begin{array}{l}6 \text { mo (insensitivity to } \\
\text { pain with falls or } \\
\text { injuries) }\end{array}$ & $\begin{array}{l}6 \text { mo (tongue and lip } \\
\text { mutilations) }\end{array}$ & $\begin{array}{l}6 \text { mo (tongue and lip } \\
\text { mutilations) }\end{array}$ & $\begin{array}{l}6 \text { mo (tongue and lip } \\
\text { mutilations) }\end{array}$ \\
\hline Absent & Reduced & Absent & Absent & Absent \\
\hline Reduced & Preserved & Preserved & Preserved & Preserved \\
\hline Absent & Reduced & Reduced & Present & Reduced \\
\hline $\begin{array}{l}\text { Absent sensory nerve action } \\
\text { potentials }\end{array}$ & N/A & Normal & $\mathrm{N} / \mathrm{A}$ & Normal \\
\hline $\begin{array}{l}\text { Loss of large and small myelinated } \\
\text { and nonmyelinated neurons }\end{array}$ & $\mathrm{N} / \mathrm{A}$ & $\begin{array}{l}\text { Loss of large and small } \\
\text { myelinated and nonmyelinated } \\
\text { neurons }\end{array}$ & $\mathrm{N} / \mathrm{A}$ & $\mathrm{N} / \mathrm{A}$ \\
\hline Absent & Present & Absent & Present & Reduced \\
\hline Present & Present & Present & Present & Present \\
\hline Present & Absent & Present & Absent & Absent \\
\hline Yes & Yes & Yes & Yes & Yes \\
\hline Normal & Normal & Normal & Increased & Normal \\
\hline No & No & No & No & No \\
\hline Normal & Normal & Normal & Normal & Normal \\
\hline $\begin{array}{l}\text { Neurogenic dysphagia, sialorrhea, } \\
\text { GERD, vomiting, and gastroparesis } \\
\text { requiring Nissen fundoplication. }\end{array}$ & No & GERD & $\begin{array}{l}\text { Neurogenic } \\
\text { dysphagia, GERD, } \\
\text { and frequent } \\
\text { vomiting requiring } \\
\text { Nissen } \\
\text { fundoplication. }\end{array}$ & $\begin{array}{l}\text { Neurogenic dysphagia, GERD, } \\
\text { requiring G-tube }\end{array}$ \\
\hline No & Central sleep apnea & No & No & $\begin{array}{l}\text { Predominantly obstructive } \\
\text { with some central apneas }\end{array}$ \\
\hline $\begin{array}{l}\text { Frequent hip dislocation and } \\
\text { scoliosis }\end{array}$ & Frequent fractures & $\begin{array}{l}\text { Frequent fractures and } \\
\text { neuropathic } \\
\text { joints-osteomyelitis }\end{array}$ & & \\
\hline $1(100 \%)$ & No & No & No & No \\
\hline Reduced & Normal & Reduced & Reduced & Reduced \\
\hline $\begin{array}{l}\text { Delayed, did not walk until } 3 \text { years } \\
\text { old }\end{array}$ & Normal & $\begin{array}{l}\text { Delayed, did not walk until } 2 \\
\text { years old }\end{array}$ & $\begin{array}{l}\text { Delayed, unable to } \\
\text { walk at age } 2 ; \text { small } \\
\text { for age }\end{array}$ & $\begin{array}{l}\text { Delayed; unable to crawl at age } \\
\text { 1. }\end{array}$ \\
\hline Reduced olfaction: UPSIT: $28 / 40$ & - & Neurodevelopmental delay & Normal brain MRI & Neurodevelopmental delay \\
\hline Lung disease & & Normal brain MRI & & Strabismus \\
\hline $\begin{array}{l}\text { Mild dysarthria and mild } \\
\text { proprioceptive ataxia }\end{array}$ & & & & Plagiocephaly \\
\hline
\end{tabular}

Normal brain MRI

TECPR2. Given their Ashkenazi Jewish ancestry, these 2 patients were initially tested for familial dysautonomia (HSAN3) with negative results. Mutations in TECPR2 have been shown to cause a familial dysautonomia-like syndrome. ${ }^{27,28}$ Our 2 
Table 2 Summary of Suspected Pathogenic Variants for a Series of 13 Patients With Congenital Sensory and Autonomic Neuropathy

\begin{tabular}{|c|c|c|c|c|c|c|c|}
\hline ID & Gene & $\begin{array}{l}\text { Suspected or known } \\
\text { pathogenic mutation }\end{array}$ & Zygosity & Inheritance & $\begin{array}{l}\text { PolyPhen2 prediction } \\
\text { effect (score) }\end{array}$ & SIFT (score) & Comment \\
\hline 1 & $S M P D L 3 A$ & c.791T>G (p.lle264Ser) & Homozygous & AR & Probably benign (0.006) & $\begin{array}{l}\text { Neutral } \\
(0.53)\end{array}$ & $\begin{array}{l}\text { Novel potential } \\
\text { candidate gene }\end{array}$ \\
\hline 2 & $S M P D L 3 A$ & c.791T>G (p.lle264Ser) & Homozygous & AR & Probably benign (0.006) & $\begin{array}{l}\text { Neutral } \\
(0.53)\end{array}$ & $\begin{array}{l}\text { Novel potential } \\
\text { candidate gene }\end{array}$ \\
\hline 3 & $N G F$ & c.433delG (p.Asp145llefs*13) & Homozygous & AR & Probably damaging (1) & $\begin{array}{l}\text { Deleterious } \\
\text { (0) }\end{array}$ & $\begin{array}{l}\text { Novel potential } \\
\text { pathogenic variant }\end{array}$ \\
\hline 4 & $N G F$ & c.433delG (p.Asp145Ilefs*13) & Homozygous & AR & Probably damaging (1) & $\begin{array}{l}\text { Deleterious } \\
\text { (0) }\end{array}$ & $\begin{array}{l}\text { Novel potential } \\
\text { pathogenic variant }\end{array}$ \\
\hline 5 & LIFR & c.1718dupT (p.Ser574llefs*6) & Homozygous & AR & Probably damaging (1) & $\begin{array}{l}\text { Deleterious } \\
\text { (0) }\end{array}$ & $\begin{array}{l}\text { Novel potential } \\
\text { pathogenic variant }\end{array}$ \\
\hline 6 & LIFR & c.1718dupT (p.Ser574llefs*6) & Homozygous & AR & Probably damaging (1) & $\begin{array}{l}\text { Deleterious } \\
\text { (0) }\end{array}$ & $\begin{array}{l}\text { Novel potential } \\
\text { pathogenic variant }\end{array}$ \\
\hline 7 & TECPR2 & c.1319delT (p.Leu440Argfs) & Homozygous & AR & N/A & N/A & $\begin{array}{l}\text { Described } \\
\text { pathogenic variant }{ }^{28}\end{array}$ \\
\hline 8 & TECPR2 & c.1319delT (p.Leu440Argfs) & Homozygous & AR & N/A & N/A & $\begin{array}{l}\text { Described } \\
\text { pathogenic variant }{ }^{28}\end{array}$ \\
\hline 9 & PLEKHN1 & c.A1091T (p.Asp364Val) & Homozygous & AR & Probably benign (0.02) & $\begin{array}{l}\text { Deleterious } \\
(0.02)\end{array}$ & $\begin{array}{l}\text { Novel potential } \\
\text { candidate gene }\end{array}$ \\
\hline 10 & SCN9A & c.2686C>T (p.Arg896Trp) & Homozygous & $A R$ & Probably damaging (1) & $\begin{array}{l}\text { Deleterious } \\
\text { (0) }\end{array}$ & $\begin{array}{l}\text { Novel potential } \\
\text { pathogenic variant }\end{array}$ \\
\hline 11 & SCN10A & c.2367C>A (p.Asn789Lys) & Heterozygous & $A D$ & $\begin{array}{l}\text { Probably damaging } \\
(0.992)\end{array}$ & $\begin{array}{l}\text { Deleterious } \\
\text { (0) }\end{array}$ & $\begin{array}{l}\text { Novel potential } \\
\text { candidate gene }\end{array}$ \\
\hline 12 & SCN11A & c.1187T>C (p.Leu396Pro) & Heterozygous & De novo & $\begin{array}{l}\text { Probably damaging } \\
(0.991)\end{array}$ & $\begin{array}{l}\text { Deleterious } \\
\text { (0) }\end{array}$ & $\begin{array}{l}\text { Described } \\
\text { pathogenic variant }{ }^{29}\end{array}$ \\
\hline \multirow[t]{2}{*}{13} & PRDM12 & $\begin{array}{l}c .503 \mathrm{G}>\mathrm{A} \text { (p.Arg168His) } \\
\text { inherited from the father }\end{array}$ & $\begin{array}{l}\text { Compound } \\
\text { heterozygous }\end{array}$ & AR & $\begin{array}{l}\text { Probably damaging } \\
(0.994)\end{array}$ & $\begin{array}{l}\text { Deleterious } \\
\text { (0) }\end{array}$ & $\begin{array}{l}\text { Novel potential } \\
\text { pathogenic variants }\end{array}$ \\
\hline & & $\begin{array}{l}\text { c.794A }>C \text { ( } p . \text { His } 265 \text { Pro) } \\
\text { inherited from the mother }\end{array}$ & & & $\begin{array}{l}\text { Probably damaging } \\
(0.999)\end{array}$ & $\begin{array}{l}\text { Deleterious } \\
\text { (0) }\end{array}$ & \\
\hline
\end{tabular}

patients (patient 1 and patient 2) share the same TECPR2 pathogenic variant and phenotype with 3 previously reported patients. ${ }^{28}$ Patient 2 had a thin corpus callosum, which has been reported before in other patients with the same TECPR2 pathogenic variant. ${ }^{28}$

\section{SCN11A}

We identified a heterozygous, de novo, SCN11A variant (p.Leu396Pro) in 1 patient (patient 3) of German/Italian ancestry. The same variant has been previously described in another patient with the similar syndrome. ${ }^{29}$ SCN11A encodes the sodium ion channel $\mathrm{Na}_{\mathrm{v}} 1.9$.

\section{Suspected Pathogenic Variants in Previously Described Genes}

\section{Nerve Growth Factor}

Heterozygous mutations in the nerve growth factor (NGF) (encoding the polypeptide NGF, key in the development of sensory and autonomic neurons) are described to cause HSAN5, a disorder characterized by congenital insensitivity to pain. ${ }^{8}$ We identified a homozygous previously undescribed potential pathogenic variant (p.Asp145Ilefs $\left.{ }^{*} 13\right)$ in 2 siblings (patients 3 and 4) of Indian ancestry. Both patients had a similar phenotype to that described in the literature, but they also had anhidrosis, which is not typical of most patients with NGF mutations.

\section{LIFR}

Biallelic mutations in the LIFR gene, encoding the receptor for leukemia-inhibitory factor, a polyfunctional cytokine that affects the differentiation, survival, and proliferation of a wide variety of cells during embryologic development, cause StüveWiedemann syndrome, a disorder characterized by skeletal changes, bowing of the lower limbs, episodic changes in temperature, and respiratory infections. ${ }^{30,31}$ Reductions in pain and temperature sensation as well as autonomic dysfunction have been described as well, although they are not usually listed as classic features of the syndrome. ${ }^{32-34} \mathrm{We}$ identified a homozygous, previously undescribed potential pathogenic variant (p.Ser574Ilefs*6) in 2 siblings (patients 5 and 6) of Pakistani ancestry, who had a similar phenotype to that described in the literature. Of note, these 2 siblings had paroxysmal episodes of hypertension and diaphoresis associated with high plasma norepinephrine levels and 
hyponatremia, requiring frequent visits to the emergency department. These episodes of diaphoresis were so severe and dramatic as to sometimes requiring the patients' clothes be changed 7-10 times a day.

\section{SNC9A}

Mutations in SCN9A (encoding the sodium ion channel $\mathrm{Na}_{\mathrm{v}}$ 1.7) have been reported in patients with either painful neuropathy or congenital insensitivity to pain, depending on the effect of the mutation on the sodium channel function. ${ }^{35,36}$ We identified a de novo homozygous previously undescribed potential pathogenic variant (p.Arg896Trp) in patient 10 with central European ancestry with a similar phenotype to that of previously described patients with congenital insensitivity to pain caused by other SCN9A mutations.

\section{PRDM12}

Variants in PRDM12 (encoding a family of transcriptional regulators that participate in the control of neurogenesis) have been described in association with autosomal recessive HSAN8, a disorder characterized by congenital insensitivity to pain, corneal ulcers, and neuropathic joints with reduced lacrimation. 12,37-39 We identified previously undescribed compound heterozygous potential pathogenic variants ( $\mathrm{p}$.Arg168His inherited from her father and p.His265Pro inherited from her mother) in a patient of Caribbean ancestry who had a similar phenotype to that described in the literature.

\section{Novel Potential Pathogenic Variants in Novel Genes}

We identified novel variants in 3 genes never associated with congenital insensitivity to pain before. These 3 newly identified variants will require further validation.

\section{SMPDL3A}

SMPDL3A encodes the protein sphingomyelin phosphodiesterase acid-like $3 \mathrm{~A}$. Although the function of this protein remains poorly understood, ${ }^{40,41}$ its sequence is homologous to the wellcharacterized acid sphingomyelinase. Acid sphingomyelinase deficiency causes Niemann-Pick disease, which is characterized by peripheral neuropathy among other manifestations. ${ }^{42,43} \mathrm{We}$ identified a homozygous SMPDL3A variant (p.Ile264Ser) in 2 siblings with similar phenotype (patients 1 and 2). This variant had conflicting results in the in silico tools, with a low CADD score (9.016), a probably benign on PolyPhen2, and neutral SIFT score. However, the allele frequency is $<0.3 \%$, and the homozygous state has never been observed in the control population, suggesting a likely pathogenic role.

\section{PLEKHN1}

PLEKHN1 encodes the protein pleckstrin-homology N1, also known as cardiolipin phosphatidic acid-binding protein. ${ }^{44}$ Its function is yet to be fully defined, but it has been reported to play a role in axonal transport and mitochondrial metabolism. ${ }^{45}$ Dysfunction in these systems has been implicated in the pathophysiology of other HSAN. ${ }^{46,47}$ We identified a homozygous PLEKHN1 missense variant (p.Asp364Val) in patient 9, who had a remarkably similar phenotype to patients with the SMPDL3A variant described above, including hyposmia, mild dysarthria, and loss of myelinated and unmyelinated fibers in sural nerve biopsy. The PLEKHN1 variant had conflicting results with in silico predicting tools, with a borderline CADD score (16.25), a deleterious SIFT score, probably benign on PolyPhen2, neutral on MutationTaster, and tolerated in FATHMM. However, it has an allele frequency of $<0.04 \%$ and the homozygous state has never been observed in control populations, suggesting a likely pathogenic role.

\section{SCN10A}

The SCN10A gene encodes sodium ion channel $\mathrm{Na}_{\mathrm{v}} 1.8$, which is highly expressed in sensory neurons. Heterozygous gain of function mutations in SCN1OA have been reported in individuals with painful small fiber peripheral neuropathy, characterized by autonomic dysfunction and burning pain in extremities. ${ }^{48} \mathrm{We}$ identified a missense heterozygous SCN10A variant (p.Asn789Lys) in patient 11, of Caribbean ancestry. All in silico tools unanimously classified the identified this SCN1OA missense variant as deleterious and damaging, making it highly likely to be pathogenic. The patient with a heterozygous SCN1OA variant had inherited it from his mother. A careful neurologic examination of the mother disclosed severely reduced albeit preserved pain and temperature perception without the other sensory or autonomic disturbances that were present in her son, suggesting that heterozygous $S C N 10 A$-associated variants may have incomplete penetrance or variable expressivity, similarly to what has been described in other hereditary neuropathies. ${ }^{49}$

\section{Protein Structure Prediction}

To further explore the functional outcomes of the sodium channel mutations, we investigated the effect of mutations in SCN genes on the protein secondary structures. We first applied MUpro ${ }^{25}$ and found that all 3 mutations in SCN9A (p.Arg896W), SCN10A (p.Asn789Lys), and SCN11A (p.Leu396Pro) resulted in decreased protein stability, with predicted changes in Gibbs free energy $(\Delta \Delta G)$ as $-0.518,-0.966$, and -1.777 , respectively. These observations indicated that these $S C N$ variations might impair the protein structures. These 3 proteins are sodium channels, with transmembrane domains, and we tested the effect of these variation on the helixes. According to neXtProt, ${ }^{50}$ the variation p.Arg896W of SCN9A is inside an extracellular domain, whereas p.Asn789Lys in SCN10A is the last amino acid of a cytoplasmic domain followed by a transmembrane domain. Only p.Leu396Pro of SCN11A is located inside a transmembrane domain. All these 3 variations were predicted to alter the protein helices by PSIPRED $^{51}$ (figure e-1, links.lww.com/NXG/A389). These results suggested all these $S C N$ mutations might interfere the organization of alpha-helices resulting in the disruption of the transmembrane or extracellular protein functions.

\section{Discussion}

Our results provide insight into the genetic landscape of congenital sensory and autonomic neuropathies. We show that whole-exome sequencing has a high probability of identifying 
the genetic cause of undiagnosed patients with congenital sensory and autonomic neuropathies that have failed earlier candidate gene approaches. Because all patients had negative results from earlier candidate gene testing, we anticipated that novel causal genes were highly likely to be identified. Likely or known pathogenic variants in known genes explained more than $60 \%$ of cases. These included novel likely pathogenic variants in NGF, LIFR, SCN9A, and PRDM12 and known pathogenic variants in TECPR2 and SCN11A.

Our results expand the phenotype-genotype correlation of genes involved in congenital sensory and autonomic neuropathies. For instance, our 2 siblings harboring novel NGF variants had anhidrosis, which is not typical of HSAN5. Anhidrosis has so far been reported only in 1 family with a specific NGF mutation (c.661C $>\mathrm{T}) .{ }^{52}$ In contrast, anhidrosis is a defining feature of congenital insensitivity to pain with anhidrosis caused by NTRK1 mutations (HSAN4). The anhidrosis in our 2 patients with NFG mutations strongly suggested that they had mutations in NTRK1 instead, contributing to the delay of the genetic diagnosis. NGF (encoded by NGF) engages 2 structurally distinct transmembrane receptors, TrkA (encoded by NTRK1) and p75, which create a high-affinity NGF binding site through the formation of a TrkA/NGF/p75 complex. ${ }^{53}$ It is tempting to hypothesize that the NGF mutations we here describe may cause a dysfunctional NGF-TrkA resulting in anhidrosis, as seen in patients with HSAN4.

Mutations in the LIFR gene cause Stüve-Wiedemann syndrome, a disorder characterized by skeletal changes with bowing of the lower limbs, hirsutism, thermoregulation abnormalities, and frequent respiratory infections. ${ }^{30,31}$ Our patients with LIFR mutations also had paroxysmal episodes of hypertension and severe diaphoresis associated with high plasma norepinephrine levels and hyponatremia, requiring frequent visits to the emergency department, resembling the dysautonomic crisis of patients with familial dysautonomia (HSAN3) ${ }^{54}$ The underlying pathophysiology of dysautonomic crisis in patients with HSAN3 is unrestrained catecholamine release in the context of afferent baroreflex failure. ${ }^{55,56}$ It is tempting to hypothesize that a similar mechanism could underlie hyperadrenergic episodes in Stüve-Wiedemann syndrome. Although Stüve-Wiedemann syndrome is not included in the classic classification of HSAN, our results strongly argue for the inclusion of LIFR mutations in the differential diagnosis of patients with congenital sensory and autonomic neuropathy. ${ }^{57}$

TECPR 2 mutations have been described to cause a familial dysautonomia-like HSAN. The disorder was initially described in 3 unrelated Jewish Bukharan families with a different mutation (p.Leu1139Argfs). ${ }^{27}$ Because some of these patients developed spasticity in older age, the disease was initially classified as a subtype of hereditary spastic paraparesis and named SPG49. A different mutation in the same gene (p.Leu440Argfs) was reported in 3 non-Bukharan patients with prominent features of sensory and autonomic neuropathy, prompting the reclassification of the disease as a HSAN. ${ }^{28}$ Our 2 unrelated patients (patients 7 and patient 8), both from Jewish Ashkenazi families, share the same mutation and the phenotype previously described in the 3 nonBukharan patients. Familial dysautonomia (HSAN3) and the disorder caused by TECPR2 mutations share similar characteristics, including neurogenic dysphagia, proprioceptive ataxia and central sleep apnea. However, in contrast to the marked blood pressure abnormalities characteristic of HSAN3, patients with TECPR2 mutations appear to have preserved cardiovascular autonomic function.

We also identified the potential novel candidate genes SMPDL3A, PLEKHN1, and SCN10A. The patients harboring SMPDL $3 A$ and PLEKHN1 variants had a remarkably similar phenotype, whereas the patient with the SCN1OA variant had a phenotype similar to that of patients with variants in $S C N 9 A$ and SCN11A causing dysfunction in sodium channels. $\mathrm{Mu}-$ tations in SCN1OA causing congenital sensory and autonomic neuropathy expand the phenotype of sodium channelopathies, which also include mutations in genes SCN9A (encoding sodium ion channel $\mathrm{Na}_{\mathrm{v}} 1.7$ ) and SCN11A (encoding sodium ion channel $\mathrm{Na}_{\mathrm{v}} 1.9$ ), as the ones here described in patient 10 and patient 12, respectively, which have been reported with both painful neuropathy and congenital insensitivity to pain, depending on the effect of the mutation on the sodium channel function. ${ }^{48,58}$ The SCN10A variant was unanimously classified as pathogenic by the in silico tools. Also, in silico prediction of the SCN protein function suggested that the $S C N$ mutations in our patients might interfere the organization of alpha-helices resulting in the disruption of the transmembrane or extracellular protein functions.

The function of both SMPDL3A and PLEKHN1 remains poorly understood, but both are related to functions or pathways involved in peripheral nerve metabolism and survival. The SMPDL3A and PLEKHN1 mutations had conflicting in silico results, although in both cases, the described frequencies of the alleles were extremely low and the homozygous state has never been observed in control populations, suggesting a likely pathogenic role. Additional cases of congenital HSAN bearing the identified variants in SMPDL3A, PLEKHN1, and SCN1OA should confirm the pathogenicity of these novel candidate genes.

Whole-exome sequencing has been previously used in cohorts of patients with inherited neuropathies ${ }^{15}$ and has been anecdotally reported in individual cases of congenital sensory and autonomic neuropathy. ${ }^{59,60}$ Here, we provide a comprehensive report of genetic etiologies in a cohort of patients with congenital sensory and autonomic neuropathy syndromes. All patients were referred to the NYU Dysautonomia Center. Although our cohort may have a referral bias, it was likely biased toward enrollment of patients without a clinical explanation. Therefore, we do not think that we have overestimated the role of genetic influences of congenital 
hereditary sensory and autonomic neuropathies. None of our patients underwent skin biopsy for the assessment of sensory and autonomic cutaneous innervation, which would have been useful to expand our genotype-phenotype correlations.

In the current era of evolving precision medicine, having an established genetic diagnosis has the potential of influencing treatment. For instance, familial dysautonomia (HSAN3) is caused by a founder mutation in the ELP1 gene, causing a preRNA splicing defect resulting in the expression of a truncated ELP1 protein. Genetic therapies, such as antisense oligonucleotides or U1 snRNAs, as well as small molecules, have shown promise to correct the splicing defect in preclinical models of familial dysautonomia. ${ }^{61-63}$ Similar therapeutic mechanisms may be useful to correcting the deleterious consequences of genetic mutations causing other HSAN. Conversely, the identified mutations may be useful to inform drug development of new analgesic drugs, and there are now therapies in the pipeline targeting NGF and sodium channels.

In summary, children with congenital sensory and autonomic neuropathies have identifiable genetic etiologies. Wholeexome sequencing should be considered on a clinical basis to expedite a definite diagnosis, reduce unnecessary laboratory investigations, and eventually guide enrollment in genespecific clinical trials as they emerge. Genetic diagnosis frequently empowers families with the knowledge to care and advocate for their children and make decisions regarding family planning. In conclusion, our findings suggest that whole-exome sequencing is of high yield in patients with congenital impaired sensation to pain and temperature.

\section{Study Funding}

NINDS (U54-NS065736-01) and Familial Dysautonomia Foundation.

\section{Disclosure}

The authors report no disclosures relevant to the manuscript. Full disclosure form information provided by the authors is available with the full text of this article at Neurology.org/NG.

\section{Publication History}

Received by Neurology: Genetics July 17, 2020. Accepted in final form February 1, 2021.

Appendix Authors

\begin{tabular}{lll}
\hline Name & Location & Contribution \\
\hline $\begin{array}{l}\text { Jose-Alberto } \\
\text { Palma, MD } \\
\text { PhD }\end{array}$ & $\begin{array}{l}\text { NYU School of } \\
\text { Medicine, New York }\end{array}$ & $\begin{array}{l}\text { Coordination of study design } \\
\text { and conduct, designing } \\
\text { research studies, acquiring } \\
\text { data, analyzing data, and } \\
\text { writing the initial draft of the } \\
\text { manuscript }\end{array}$ \\
& & $\begin{array}{l}\text { Analyzing data, significant } \\
\text { contribution to the } \\
\text { Rachita Yadav, } \\
\text { PhD }\end{array}$ \\
& $\begin{array}{l}\text { Massachusetts } \\
\text { General Hospital } \\
\text { Research Institute, } \\
\text { Boston }\end{array}$ & approval \\
\hline
\end{tabular}

\section{Appendix (continued)}

\begin{tabular}{|c|c|c|}
\hline Name & Location & Contribution \\
\hline Dadi Gao, PhD & $\begin{array}{l}\text { Massachusetts } \\
\text { General Hospital } \\
\text { Research Institute, } \\
\text { Boston }\end{array}$ & $\begin{array}{l}\text { Analyzing data, significant } \\
\text { contribution to the } \\
\text { manuscript, and final } \\
\text { approval }\end{array}$ \\
\hline $\begin{array}{l}\text { Lucy Norcliffe- } \\
\text { Kaufmann, } \\
\text { PhD }\end{array}$ & $\begin{array}{l}\text { NYU School of } \\
\text { Medicine, New York }\end{array}$ & $\begin{array}{l}\text { Analyzing data, significant } \\
\text { contribution to the } \\
\text { manuscript, and final } \\
\text { approval. }\end{array}$ \\
\hline $\begin{array}{l}\text { Susan A. } \\
\text { Slaugenhaupt, } \\
\text { PhD }\end{array}$ & $\begin{array}{l}\text { Massachusetts } \\
\text { General Hospital } \\
\text { Research Institute, } \\
\text { Boston }\end{array}$ & $\begin{array}{l}\text { Analyzing data, significant } \\
\text { contribution to the } \\
\text { manuscript, and final } \\
\text { approval }\end{array}$ \\
\hline $\begin{array}{l}\text { Horacio } \\
\text { Kaufmann, MD }\end{array}$ & $\begin{array}{l}\text { NYU School of } \\
\text { Medicine, New York }\end{array}$ & $\begin{array}{l}\text { Designing research studies, } \\
\text { acquiring data, analyzing } \\
\text { data, providing reagents, } \\
\text { and writing the initial draft of } \\
\text { the manuscript }\end{array}$ \\
\hline
\end{tabular}

\section{References}

1. Dyck PJ. Neuronal atrophy and degeneration predominantly affecting peripheral sensory and autonomic neurons. In: Dyck PJ, Thomas PK, Griffin JW, Low PA, Poduslo JF, editors. Peripheral Neuropathy. Philadelphia: W.B. Saunders; 1993:1065-1093.

2. Axelrod FB, Gold-von Simson G. Hereditary sensory and autonomic neuropathies: types II, III, and IV. Orphanet J Rare Dis 2007;2:39.

3. Lafreniere RG, MacDonald ML, Dube MP, et al. Identification of a novel gene (HSN2) causing hereditary sensory and autonomic neuropathy type II through the Study of Canadian Genetic Isolates. Am J Hum Genet 2004;74:1064-1073.

4. Riviere JB, Ramalingam S, Lavastre V, et al. KIF1A, an axonal transporter of synaptic vesicles, is mutated in hereditary sensory and autonomic neuropathy type 2 . Am J Hum Genet 2011;89:219-230.

5. Slaugenhaupt SA, Blumenfeld A, Gill SP, et al. Tissue-specific expression of a splicing mutation in the IKBKAP gene causes familial dysautonomia. Am J Hum Genet 2001; 68:598-605.

6. Indo Y, Tsuruta M, Hayashida Y, et al. Mutations in the TRKA/NGF receptor gene in patients with congenital insensitivity to pain with anhidrosis. Nat Genet 1996;13: 485-488.

7. Rotthier A, Baets J, De Vriendt E, et al. Genes for hereditary sensory and autonomic neuropathies: a genotype-phenotype correlation. Brain 2009;132:2699-2711.

8. Einarsdottir E, Carlsson A, Minde J, et al. A mutation in the nerve growth factor beta gene (NGFB) causes loss of pain perception. Hum Mol Genet 2004;13:799-805.

9. Lynch-Godrei A, Kothary R. HSAN-VI: a spectrum disorder based on dystonin isoform expression. Neurol Genet 2020;6:e389.

10. Manganelli F, Parisi S, Nolano M, et al. Novel mutations in dystonin provide clues to the pathomechanisms of HSAN-VI. Neurology 2017;88:2132-2140.

11. Leipold E, Liebmann L, Korenke GC, et al. A de novo gain-of-function mutation in SCN11A causes loss of pain perception. Nat Genet 2013;45:1399-1404.

12. Chen YC, Auer-Grumbach M, Matsukawa S, et al. Transcriptional regulator PRDM12 is essential for human pain perception. Nat Genet 2015;47:803-808.

13. Verpoorten N, De Jonghe P, Timmerman V. Disease mechanisms in hereditary sensory and autonomic neuropathies. Neurobiol Dis 2006;21:247-255.

14. Biesecker LG, Green RC. Diagnostic clinical genome and exome sequencing. N Engl J Med 2014;370:2418-2425.

15. Klein CJ, Middha S, Duan X, et al. Application of whole exome sequencing in undiagnosed inherited polyneuropathies. J Neurol Neurosurg Psychiatry 2014;85: $1265-1272$.

16. Adzhubei IA, Schmidt S, Peshkin L, et al. A method and server for predicting damaging missense mutations. Nat Methods 2010;7:248-249.

17. Ng PC, Henikoff S. SIFT: predicting amino acid changes that affect protein function. Nucleic Acids Res 2003;31:3812-3814.

18. Rentzsch P, Witten D, Cooper GM, Shendure J, Kircher M. CADD: predicting the deleteriousness of variants throughout the human genome. Nucleic Acids Res 2019; 47:D886-D894.

19. LOFTEE (Loss-Of-Function Transcript Effect Estimator) [online]. Available at: github.com/konradjk/loftee. Accessed April 24, 2019.

20. Schwarz JM, Cooper DN, Schuelke M, Seelow D. MutationTaster2: mutation prediction for the deep-sequencing age. Nat Methods 2014;11:361-362.

21. Dong C, Wei P, Jian X, et al. Comparison and integration of deleteriousness prediction methods for nonsynonymous SNVs in whole exome sequencing studies. Hum Mol Genet 2015;24:2125-2137.

22. Shihab HA, Gough J, Mort M, Cooper DN, Day IN, Gaunt TR. Ranking nonsynonymous single nucleotide polymorphisms based on disease concepts. Hum Genomics 2014;8:11. 
23. Karczewski KJ, Francioli LC, Tiao G, et al. The mutational constraint spectrum quantified from variation in 141,456 humans. Nature 2020;581:434-443.

24. Genomes Project C, Auton A, Brooks LD, et al. A global reference for human genetic variation. Nature 2015;526:68-74.

25. Cheng J, Randall A, Baldi P. Prediction of protein stability changes for single-site mutations using support vector machines. Proteins 2006;62:1125-1132.

26. Little J, Higgins JP, Ioannidis JP, et al. STrengthening the REporting of Genetic Association Studies (STREGA): an extension of the STROBE statement. PLoS Med 2009;6:e22.

27. Oz-Levi D, Ben-Zeev B, Ruzzo EK, et al. Mutation in TECPR2 reveals a role for autophagy in hereditary spastic paraparesis. Am J Hum Genet 2012;91:1065-1072.

28. Heimer G, Oz-Levi D, Eyal E, et al. TECPR2 mutations cause a new subtype of familial dysautonomia like hereditary sensory autonomic neuropathy with intellectual disability. Eur J Paediatr Neurol 2016;20:69-79.

29. King MK, Leipold E, Goehringer JM, Kurth I, Challman TD. Pain insensitivity: distal S6segment mutations in NaV1.9 emerge as critical hotspot. Neurogenetics 2017;18:179-181.

30. Dagoneau N, Scheffer D, Huber C, et al. Null leukemia inhibitory factor receptor (LIFR) mutations in Stuve-Wiedemann/Schwartz-Jampel type 2 syndrome. Am J Hum Genet 2004;74:298-305.

31. Wiedemann HR, Stuve A. Stuve-Wiedemann syndrome: update and historical footnote. Am J Med Genet 1996;63:12-16.

32. Di Rocco M, Stella G, Bruno C, Doria Lamba L, Bado M, Superti-Furga A. Long-term survival in Stuve-Wiedemann syndrome: a neuro-myo-skeletal disorder with manifestations of dysautonomia. Am J Med Genet A 2003;118A:362-368.

33. Melone MA, Pellegrino MJ, Nolano M, et al. Unusual Stuve-Wiedemann syndrome with complete maternal chromosome 5 isodisomy. Ann Clin Transl Neurol 2014;1: 926-932.

34. Axelrod FB, Pearson J, Tepperberg J, Ackerman BD. Congenital sensory neuropathy with skeletal dysplasia. J Pediatr 1983;102:727-730.

35. Cox JJ, Reimann F, Nicholas AK, et al. An SCN9A channelopathy causes congenital inability to experience pain. Nature 2006;444:894-898.

36. Li QS, Cheng P, Favis R, Wickenden A, Romano G, Wang H. SCN9A variants may be implicated in neuropathic pain associated with diabetic peripheral neuropathy and pain severity. Clin J Pain 2015;31:976-982.

37. Saini AG, Padmanabh H, Sahu JK, Kurth I, Voigt M, Singhi P. Hereditary sensory polyneuropathy, pain insensitivity and global developmental delay due to novel mutation in PRDM12 gene. Indian J Pediatr 2017;84:332-333.

38. Zhang S, Malik Sharif S, Chen YC, et al. Clinical features for diagnosis and management of patients with PRDM12 congenital insensitivity to pain. J Med Genet 2016; 53:533-535.

39. Nagy V, Cole T, Van Campenhout C, et al. The evolutionarily conserved transcription factor PRDM12 controls sensory neuron development and pain perception. Cell Cycle 2015;14:1799-1808.

40. Traini M, Kumaran R, Thaysen-Andersen M, Kockx M, Jessup W, Kritharides L. Nglycosylation of human sphingomyelin phosphodiesterase acid-like 3A (SMPDL3A) is essential for stability, secretion and activity. Biochem J 2017;474:1071-1092.

41. Traini M, Quinn CM, Sandoval C, et al. Sphingomyelin phosphodiesterase acid-like 3A (SMPDL3A) is a novel nucleotide phosphodiesterase regulated by cholesterol in human macrophages. J Biol Chem 2014;289:32895-32913.

42. Gumbinas M, Larsen M, Mei Liu H. Peripheral neuropathy in classic Niemann-Pick disease: ultrastructure of nerves and skeletal muscles. Neurology 1975;25:107-113.

43. Landrieu P, Said G. Peripheral neuropathy in type A Niemann-Pick disease. A morphological study. Acta Neuropathol 1984;63:66-71.
44. Kuriyama S, Tsuji T, Sakuma T, Yamamoto T, Tanaka M. PLEKHN1 promotes apoptosis by enhancing Bax-Bak hetro-oligomerization through interaction with $\mathrm{Bid}$ in human colon cancer. Cell Death Discov 2018;4:11.

45. Sano E, Shono S, Tashiro K, Konishi H, Yamauchi E, Taniguchi H. Novel tyrosine phosphorylated and cardiolipin-binding protein CLPABP functions as mitochondrial RNA granule. Biochim Biophys Acta 2008;1783:1036-1047.

46. Tourtellotte WG. Axon transport and neuropathy: relevant perspectives on the etiopathogenesis of familial dysautonomia. Am J Pathol 2016;186:489-499.

47. Ohlen SB, Russell ML, Brownstein MJ, Lefcort F. BGP-15 prevents the death of neurons in a mouse model of familial dysautonomia. Proc Natl Acad Sci U S A 2017; 114:5035-5040.

48. Faber CG, Lauria G, Merkies IS, et al. Gain-of-function Nav1.8 mutations in painful neuropathy. Proc Natl Acad Sci U S A 2012;109:19444-19449.

49. Nakhro K, Park JM, Choi BO, Chung KW. Missense mutations of mitofusin 2 in axonal Charcot-Marie-Tooth neuropathy: polymorphic or incomplete penetration? Anim Cell Syst 2013;17:228-236.

50. Zahn-Zabal M, Michel PA, Gateau A, et al. The neXtProt knowledgebase in 2020 data, tools and usability improvements. Nucleic Acids Res 2020;48:D328-D334.

51. Buchan DWA, Jones DT. The PSIPRED protein analysis workbench: 20 years on. Nucleic Acids Res 2019;47:W402-W407.

52. Carvalho OP, Thornton GK, Hertecant J, et al. A novel NGF mutation clarifies the molecular mechanism and extends the phenotypic spectrum of the HSAN5 neuropathy. J Med Genet 2011;48:131-135.

53. Wehrman T, He X, Raab B, Dukipatti A, Blau H, Garcia KC. Structural and mechanistic insights into nerve growth factor interactions with the TrkA and $\mathrm{p} 75$ receptors. Neuron 2007;53:25-38.

54. Norcliffe-Kaufmann L, Slaugenhaupt SA, Kaufmann H. Familial dysautonomia: history, genotype, phenotype and translational research. Prog Neurobiol 2017;152:131-148.

55. Norcliffe-Kaufmann L, Martinez J, Axelrod F, Kaufmann H. Hyperdopaminergic crises in familial dysautonomia: a randomized trial of carbidopa. Neurology 2013;80: 1611-1617.

56. Norcliffe-Kaufmann L, Axelrod F, Kaufmann H. Afferent baroreflex failure in familial dysautonomia. Neurology 2010;75:1904-1911.

57. Elsaid MF, Chalhoub N, Kamel H, et al. Non-truncating LIFR mutation: causal for prominent congenital pain insensitivity phenotype with progressive vertebral destruction? Clin Genet 2016;89:210-216.

58. Huang J, Han C, Estacion M, et al. Gain-of-function mutations in sodium channel $\mathrm{Na}(\mathrm{v}) 1.9$ in painful neuropathy. Brain 2014;137:1627-1642

59. Kurth I, Baumgartner M, Schabhuttl M, et al. Whole exome sequencing in congenital pain insensitivity identifies a novel causative intronic NTRK1-mutation due to uniparental disomy. Am J Med Genet B Neuropsychiatr Genet 2016;171:875-878.

60. Altassan R, Saud HA, Masoodi TA, et al. Exome sequencing identifies novel NTRK1 mutations in patients with HSAN-IV phenotype. Am J Med Genet A 2017;173: 1009-1016.

61. Sinha R, Kim YJ, Nomakuchi T, et al. Antisense oligonucleotides correct the familial dysautonomia splicing defect in IKBKAP transgenic mice. Nucleic Acids Res 2018;46: 4833-4844

62. Donadon I, Pinotti M, Rajkowska K, et al. Exon-specific U1 snRNAs improve ELP1 exon 20 definition and rescue ELP1 protein expression in a familial dysautonomia mouse model. Hum Mol Genet 2018;27:2466-2476.

63. Morini E, Gao D, Montgomery CM, et al. ELP1 splicing correction reverses proprioceptive sensory loss in familial dysautonomia. Am J Hum Genet 2019;104: $638-650$. 


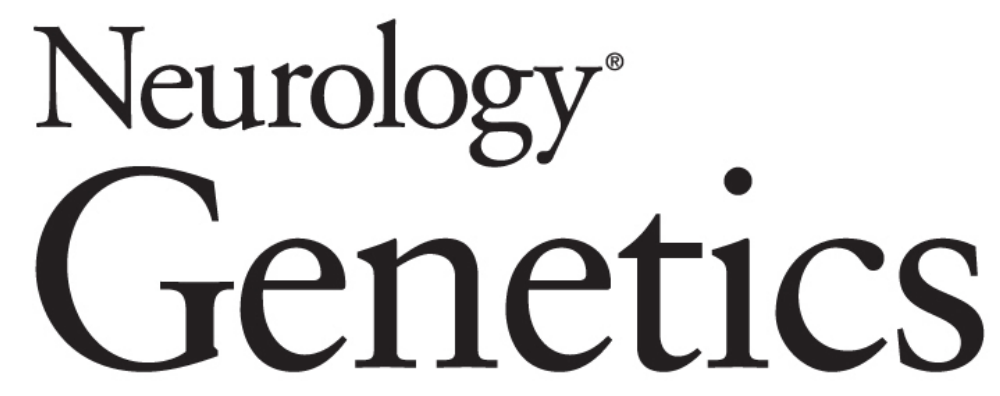

\section{Expanding the Genotypic Spectrum of Congenital Sensory and Autonomic Neuropathies Using Whole-Exome Sequencing \\ Jose-Alberto Palma, Rachita Yadav, Dadi Gao, et al. Neurol Genet 2021;7; \\ DOI 10.1212/NXG.0000000000000568}

\section{This information is current as of March 5, 2021}

\section{Updated Information \& Services}

References

Subspecialty Collections

Permissions \& Licensing

Reprints including high resolution figures, can be found at: http://ng.neurology.org/content/7/2/e568.full.html

This article cites 61 articles, 8 of which you can access for free at: http://ng.neurology.org/content/7/2/e568.full.html\#\#ref-list-1

This article, along with others on similar topics, appears in the following collection(s):

All Genetics

http://ng.neurology.org//cgi/collection/all_genetics

All Pain

http://ng.neurology.org//cgi/collection/all_pain

All Pediatric

http://ng.neurology.org//cgi/collection/all_pediatric

Autonomic diseases

http://ng.neurology.org//cgi/collection/autonomic_diseases

Information about reproducing this article in parts (figures,tables) or in its entirety can be found online at:

http://ng.neurology.org/misc/about.xhtml\#permissions

Information about ordering reprints can be found online: http://ng.neurology.org/misc/addir.xhtml\#reprintsus

Neurol Genet is an official journal of the American Academy of Neurology. Published since April 2015, it is an open-access, online-only, continuous publication journal. Copyright Copyright $(9) 2021$ The Author(s). Published by Wolters Kluwer Health, Inc. on behalf of the American Academy of Neurology.. All rights reserved. Online ISSN: 2376-7839.

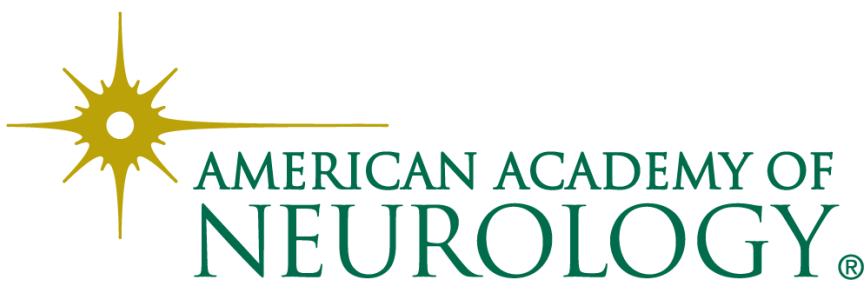

